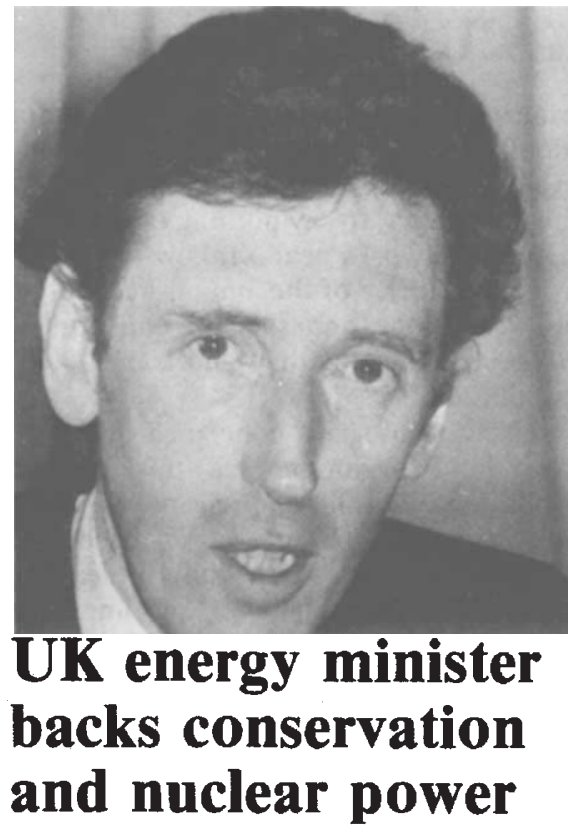

"We must have a balanced energy policy, drawing on every one of the resources available to us', David Howell, Britain's Secretary of State for Energy, told a gathering to celebrate 25 years of the UK Atomic Energy Authority last week.

$\mathrm{Mr}$ Howell (above) backed nuclear power - without it, he said, the UK "would not have a realistic policy for meeting this country's long-term energy requirements"'. But he also stressed the need to tap coal, and conservation, "where savings of $30 \%$ or more are available"'. Mr Howell announced that he was reviewing the UK conservation programme "to see what reinforcement may be necessary in this key part of our energy strategy"'

\section{UK fellowship scheme approved - in principle}

BRITAIN'S Science Research Council has given general approval to the establishment of a programme aimed at easing the critical staff stagnation problem which now affects the country's universities. However, its central council last week decided to call for more specific details before giving the final go-ahead to the scheme which would provide special release fellowships to help senior research workers vacate tenured posts that could then be filled by young scientists.

There are a number of drawbacks associated with the scheme but council members were particularly concerned that the programme, which could cost up to $£ 450,000$, could give universities an excuse to cut back on their own financing of science departments and transfer funds to other faculties. To prevent this, more specific regulations are now being prepared and the plan will be discussed by the SRC again in the autumn.

\title{
China eases ideological grip
}

"CLIMATE" science in the last sixty years" is the title of an article appearing in a recent issue of Hong qi (Red Flag) written by Chou Pei-yuan - who is in charge of the Chinese Scientific and Technological Association.

Chou expresses his opinion on the further progress of Chinese science, and refers to the role of marxism. While no substitute for science proper, materialism and the dialectics of nature nevertheless constitute a powerful methodological tool in scientific research. He quotes the 'straton' model of hadrons in particle physics and the chemical synthesis of biologically active insulin as examples of advances made by Chinese scientists under the guidance of marxian ontology.

On the other hand, real scientific discoveries may also be made by experimentalists who are not consciously materialists and dialecticians. In the development of any discipline, the general policy should be "let a hundred schools contend", he says. Academic freedom includes the understanding that no scientific model or theory will be rejected, or supported, purely on the basis of politico-philosophical arguments. Lysenko-type mistakes, such as the uncritical refutation in the late 1950 s of western psychology, must be avoided.

Chou also reviews the slow and uncertain development of science in China before 1949, when research was hampered by the lack of experimental facilities, and when significant original work was confirmed to geology, biology, palaeontology, archaeology and

\section{Yugoslavia: no more oil burning}

YugosLavia's Federal Chamber last week passed an emergency law, banning for the time being any further investment in new power stations and heating plants based on liquid fuel. This move follows a report from the Federal Executive Council which noted that, as a result of increased OPEC prices, Yugoslavia's oil import bill for 1979 will be 37,650 dinars, some $72 \%$ higher than the original estimate. Furthermore, increased domestic consumption is unable to keep up with existing supplies, so that last month, for example, certain Yugoslav airports were closed for several days, due to a total lack of aviation fuel.

The emergency bill, however, did not have an easy passage. Originally scheduled for 27 June, it was held up for three weeks by the delegates from Vojevodina province, who demanded a special procedure and moratorium, claiming that the law would endanger the vital interests of the province, and that the situation did not justify a state of emergency. Vojevodina has small but promising oil resources of its own, and recent prospecting operations by the Naftagas mathematics. He describes how Chinese science developed in the quarter century after 1949 with the socialist transformation of scientifgic and educational institutions. However, in the last few years, research of a fundamental nature has been largely neglected, and, he says this needs to be remedied quic'sly.

Chou's final point about the position of scientists is perhaps the most problematical. He mentions the phenomenon of being "hot at both ends but cold in the middle"': that the enthusiasm for scientific modernisation among the top leadership and the rankand-file scientists does not find its way to the mid-level cadres in some parts of the country. He argues that the majority of intellectuals in China are now part of the working class, and that more say in the administration and funding of science should be given to the scientists themselves. They should have the right working conditions so they can concentrate on research. Other problems which need attending to are the rational allocation of research duties to specialists and the implementation of arrangements to reduce the amount of time they spend on household labour.

T.B.Tang

- China is to spend $£ 3,500$ million on cultural, educational, scientific research and health undertakings this year. Nearly half of it will be devoted to the running of institutes under the Academia Sinica and to maintaining scientific research various other departments, according to the latest state budget announcement.

enterprise suggest that in the future, Vojevodina may be able to supply up to $5 \%$ of the crude oil required by the Belgrade, Novi Sad and Pancevo refineries.

In spite of these discoveries, Yugoslavia's energy planners are rapidly rethinking their strategies to include new developments of the abundant lignite reserves and a re-emphasis on the country's coal mines, many of which have been closed in recent years. Nuclear power, too, receives a new emphasis, and it is hoped to commission one new nuclear plant a year, from 1990 onwards. However, additional funding for the first such plant, at Krsko, is still on the "pending" list of investment, while the proposed site of the second such station on Vir island has had to be abandoned, following protests by local residents and tourist enterprises. As an extraordinary measure, the station will now be built at Prevlaka, a village on the Sava near Zagreb, although Rade Pavlovic, head of the Croation Electricity Board, stresses that all such stations in the future will have to be built on the coast.

Vera Rich 